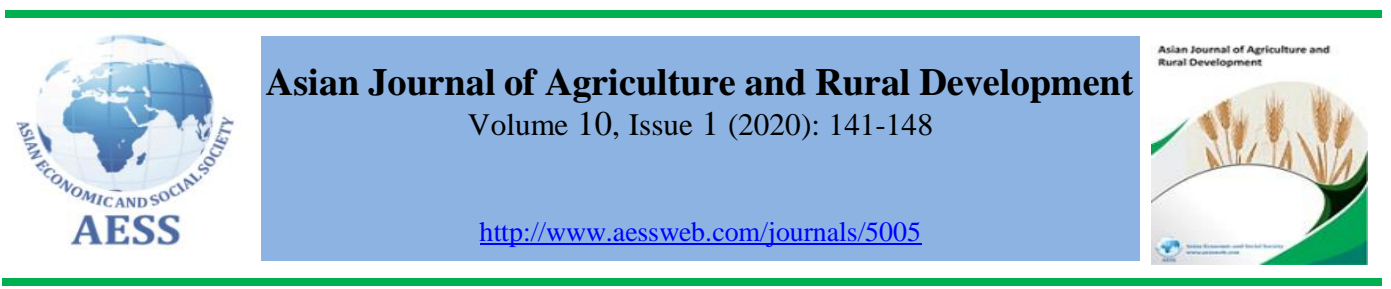

\title{
THE RELATIONSHIP BETWEEN SOCIOECONOMIC STATUS AND CONSUMPTION PATTERN OF FISHERMEN HOUSEHOLD IN INDONESIA
}

\author{
A. Rusdiana ${ }^{a}$, \\ Sanuri ${ }^{\text {, }}$, \\ Muhammad \\ Subandi ${ }^{\mathrm{c}}$, \\ Setia Mulyawan ${ }^{\mathrm{d}}$ \\ a State Islamic University, Sunan Gunung Djati, Bandung, \\ Indonesia \\ ${ }^{\mathrm{b}}$ Prince Dharma Kusuma Islamic High School Segaran Indramayu, \\ West Java- Indonesia \\ c Faculty of Science and Technology, State Islamic University, \\ Sunan Gunung Djati, Bandung, Indonesia \\ d Faculty of Business Economics, State Islamic University, Sunan \\ Gunung Djati, Bandung, Indonesia
}

\section{\rusdiana@uinsgd.ac.id (Corresponding author)}

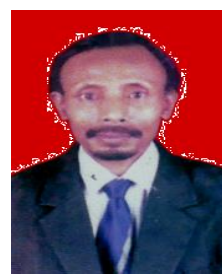

Corresponding

author

\section{ARTICLE HISTORY:}

Received: 27-Dec-2019

Accepted: 06-Mar-2020

Online Available: 30-Mar-

2020

\section{Keywords:}

Education,

Knowledge,

Ability,

Skills,

Consumptive

\begin{abstract}
The purpose of this study is to analyze the relationship between socioeconomic status and consumption patterns of fishermen households in Karangsong Village, Indramayu Regency West Java Indonesia. The importance of this paper comes from the phenomenon of the lifestyle of the fishermen community who is known in general for their very harsh character. This is because their lifestyle is very dependent on nature. Even though in certain seasons fishermen's income will grow very high but in the following seasons, fishermen's income will decrease or even will be not existent. This is what causes fishermen are in the low level of social class. For this purpose, a survey was conducted to 81 fishermen during the month of August to September in 2019. Data was collected according to simple descriptive or multivariate statistical analyzes as well as qualitative techniques. The results of this study indicate that the income and number of family members influence the consumption patterns of fishermen households. It also can be concluded that there is a positive and significant impact between the independent variables (income, number of family members and education), on the consumption patterns of fishermen households.
\end{abstract}

\section{Contribution/ Originality}

This study is one of few studies that have been investigated about the relationship between socioeconomic status and consumption patterns of fishing households. This study contributes to the first logical analysis that there is a positive and significant influence between the independent variables (income and number of family members) on the consumption patterns of fisherman households.

DOI: 10.18488/journal.1005/2020.10.1/1005.1.141.148

ISSN (P): 2304-1455/ISSN (E):2224-4433

How to cite: A. Rusdiana, Sanuri, Muhammad Subandi and Setia Mulyawan (2020). The Relationship between Socioeconomic Status and Consumption Pattern of Fishermen Household in Indonesia. Asian Journal of Agriculture and Rural Development, 10(1), 141-148.

\section{(C) 2020 Asian Economic and Social Society. All rights reserved.}




\section{INTRODUCTION}

Indonesia is an archipelago, which consists of many islands. Various Indonesian territories have coastal region. Most of the people around the coastal area earn income from the fisheries sector. The potential of fisheries resources is the ability of the waters to be utilized in the fisheries business, so it can produce a certain amount in economic growth of Indonesia. Many fishermen households depend on the fisheries sector. The fishermen community is the main social unit in the life of the coastal community, so the culture of the fishing community is the most important pillar of the culture of the coastal community (Carera, 2017). Activities by fishermen are carried out in territorial waters that are not in the category of an aquaculture business. However, in general the word fisherman is very attached to those who do fishing at sea including ship technicians and crew (Fielnanda, 2018).

Karangsong Village, one of the coastal villages in the Indramayu Regency, West Java province of Indonesia, is surrounded by a vast ocean that can create livelihoods for its residents. Karangsong village has most of his people work as fishermen who do their business with very traditional tools. It keeps their level of income relatively lower. This will also have an impact on meeting the basic needs of the fishermen's household, especially their consumption patterns. Household consumption can be divided into basic needs (primary) and supporting needs (secondary) (Fausi, 2017). In daily life, everyone is always related to consumption, whether it is to meet the need for food, health, education, and entertainment etc.

Riyadi (2011) states that higher the level of education and knowledge possessed by a person is generally the higher the awareness to meet a balanced amount of consumption and meet nutritional and selective requirements in relation to food supply. Similarly, Raharja and Mandala (2005) states that higher a person's education the consumption spending will also be higher, thus affecting the amount of consumption positively. The wasteful lifestyle is a manifestation of the consequence of pursuing worldly social honour, so such a lifestyle reflects a simple perspective to pursue the pleasures of life for a moment, where the sea will always provide income for all time (Kusnadi, 2007). The facts show that, in principle, fisherman communities with high income levels and the condition of the waters where they carry out fishing activities have a large enough potential for fishery resources tend to spend extravagant lifestyles based on the normal size of meeting their daily needs.

Cindy (2016) concluded that level of household income, the number of family members, age, and the amount of expenditure per day has a significant effect on the pattern of household food consumption, while partially the variable number of family members, age and number expenditure per day has a significant effect on household food consumption patterns. Study by Vidiawan and Tisnawati (2014) states that education has a positive and significant effect on the consumption patterns of poor households. Fajar et al. (2016) showed that the area of maize land had a positive effect on household income of corn farmers, the level of education was not significant, the number of household members had a positive influence on the household income, food expenditure has a negative effect on household income and non-food expenditure has a significant negative effect on household income level.

The pattern of life of the fisherman community is generally known for its very harsh character. This is because the fishermen's lifestyle is very dependent on nature. Even though in certain seasons fishermen's income is very high, and vice versa. This has caused or encouraged fishermen to be in the low social class life even for their daily needs. However, fishermen also have a consumptive lifestyle. So, when their incomes are high their consumption patterns are also high. However, when income is low, they still survive by selling their valuables or debt receivables with very high interest (Aries, 2015). 
Numerous variables affect household or community consumption patterns. Among them are income, education and living environment variables. Income plays an important role in determining the consumption patterns of individuals, households, communities and governments. Because fisherman communities do not get enough income every day to meet their family's needs, non-permanent income will affect family consumption. This variable income is not balanced with the needs of everyday life that is very much. This can lead to imbalance between meeting needs with income (Vidiawan and Tisnawati, 2014; Mayasari et al., 2018).

Conceptually, consumption patterns are human needs in the form of objects and services that is allocated to personal interests as well as families based on governance and responsibilities that are realized as primary and secondary needs (Astari, 2016). The consumption pattern is the composition of food which includes the type and amount of food ingredients for a person per day, which is generally consumed by the population within a certain period. The consumption patterns give an overview of the type and amount of food consumed every day by one person that is characteristic of a community group. The factors influence consumption patterns, includes the consumer's income \& tastes, the price of goods (Carera, 2017; Mayasari et al., 2018).

Some economists reveal that food can be an indicator for assessing the level of economic prosperity of the community. Mayasari et al. (2018) state that the higher the welfare of the people of a country, the lower the proportion of food expenditure of its population, and vice versa. Household food expenditure will rise in line with increasing income but the proportion of food expenditure from total income will decrease.

Pande (2012) finds that the most important factors affecting consumption behavior are income and culture. Furthermore, Vidiawan and Tisnawati (2014), adds that in the national economy, national consumption is influenced by national income, deposit rates and inflation. Income reflects a person's ability to consume both quality and quantity. In addition to income, consumption is also influenced by the number of family members. Fewer family members mean fewer needs for the family to fulfill. The large number of family members causes the family consumption pattern will be more varied because each family member may not necessarily have the same consumption pattern. Thus, there are many variables that influence household or community consumption patterns, including income, family size, education and neighborhood. Education and income play an important role in determining the consumption patterns of individuals, households, communities and governments.

This study focuses on fishermen Household Consumption Pattern in the coastal village of Karansong, Indramayu district, Indramayu Regency, West Java province, Indonesia. It is generally known that fishermen are one of the members of the community who have the lowest level of welfare, this is characterized by a slum environment and simple houses, if there is a complete house generally owned by boat owners and financiers, in addition, fishing communities when they get a high income, they tend to have a wasteful lifestyle. Hence, it would be interesting to study the area on the coast of the district center with a lack of educational facilities, low income and education of the local community. So, how does the consumption pattern of the local community meet their daily needs, both basic and supplementary need? What consumption patterns do they do every day? With the answer to the problem, this study is among the few studies that have been investigated to analyze the effect of income and family members on fishermen household consumption patterns.

\section{METHODS AND RESEARCH TOOLS}

This is an exploratory research that focuses on explanations about concepts or patterns. The analysis focused on the depth of data obtained from the study sample. Quantitative data is used for analysis. To deepen the results of the analysis literature reviews and field surveys have been carried 
out on the phenomenon of the Fishermen community in the Coastal Village of Karangsong, Indramayu Regency, West Java province. Data analysis was carried out by distributing questionnaires to 81 research samples. Determination of the number of samples performed by referring to the opinion of Uma (2006), which states that the rules of thumb amount of research data ranged from 30 to 500 people. The consumption approach is one that is often analyze the income of farmers. The income will ultimately affect the consumption patterns of each of these households. The household takes the decision to allocate part of its budget to buy food and nonfood needs. Spending on food, clothing, and other need is classified as consumption (Fausi, 2017).

Consumption expenditure is largely determined by the size of income, where between income and consumption has a positive relationship. Keynes says that there is a minimum consumption expenditure that must be carried out by society (autonomous consumption) and consumption expenditure will increase as income increases (Fausi, 2017). Fielnanda (2018) also states about the relationship of consumption expenditure with national income measured by constant prices. The Keynesian consumption function is formulated as following:

$$
C=C_{0}+b Y d
$$

Where:

$\mathrm{C}=$ consumption

$\mathrm{C}_{0}=$ autonomous consumption

$\mathrm{b}=$ marginal propensity to consume (MPC)

$\mathrm{Yd}=$ disposable income

\section{RESULTS AND DISCUSSION}

Table 1 consists of descriptive statistics of the income variable. The income variable consists of five items.

Table 1: Statistical description of income variable

\begin{tabular}{lccccccccccc}
\hline \multirow{2}{*}{ Statement } & \multicolumn{4}{c}{ Static } & \multicolumn{3}{c}{ Total } & \multicolumn{3}{c}{ Percentage } \\
& STS & TS & N & S & SS & & STS & TS & N & S & SS \\
\hline Statement 1 & 0 & 9 & 40 & 29 & 3 & 81 & 0 & 11.1 & 49.4 & 35.8 & 3.7 \\
Statement 2 & 0 & 17 & 36 & 25 & 3 & 81 & 0 & 21 & 44.4 & 30.9 & 3.7 \\
Statement 3 & 0 & 20 & 41 & 19 & 1 & 81 & 0 & 24.7 & 50.6 & 23.55 & 1.2 \\
Statement 4 & 0 & 17 & 32 & 29 & 3 & 81 & 0 & 21 & 39.5 & 35.8 & 3.7 \\
Statement 5 & 0 & 10 & 28 & 32 & 1 & 81 & 0 & 12.3 & 34.6 & 39.5 & 1.2 \\
Amount & 0 & 73 & 187 & 134 & 11 & 405 & 0 & 18 & 46.35 & 33.1 & 2.7 \\
\hline
\end{tabular}

Based on Table 1, it is concluded that the income from fishermen can meet daily needs (STS) by $0 \%$, the higher the level of income of fishermen, the higher the non-food consumption compared to food consumption (TS) by $18 \%$. Increasing the catch of fishermen can increase income (N) by $46.35 \%$. The existence of side jobs from the head of the family can increase income (S) by $33.1 \%$, and the presence of family members who work other than the head of the family can increase consumption patterns (SS) by $2.7 \%$.

The catch of fishing communities that are uncertain is influenced by natural conditions. Considering the uncertain income will affect the consumption pattern of the fisherman community. Uncertain income creates a need with unbalanced income. However, when the income of fishermen increases, the needs and income are balanced. At the time of low income fisherman communities also reduce consumption spending (Junaidi et al., 2019). 
Table 2 consists of descriptive statistics of the variable, number of family members. The variable also consists of five items.

Table 2: Statistical description of the family numbers and education variable

\begin{tabular}{lccccccccccc}
\hline \multirow{2}{*}{ Statements } & \multicolumn{4}{c}{ Static } & \multicolumn{3}{c}{ Total } & \multicolumn{5}{c}{ Percentage } \\
& STS & TS & N & S & SS & & STS & TS & N & S & SS \\
\hline Statement 1 & 0 & 2 & 23 & 46 & 11 & 81 & 0 & 1.2 & 28.4 & 56.8 & 13.6 \\
Statement 2 & 0 & 1 & 20 & 54 & 6 & 81 & 0 & 1.2 & 24.7 & 66.7 & 7.4 \\
Statement 3 & 0 & 10 & 20 & 44 & 7 & 81 & 0 & 12.3 & 24.7 & 54.3 & 8.6 \\
Statement 4 & 0 & 1 & 42 & 28 & 10 & 81 & 0 & 1.2 & 51.9 & 34.6 & 12.3 \\
Statement 5 & 0 & 3 & 25 & 43 & 10 & 81 & 0 & 3.7 & 30.9 & 53.1 & 12.3 \\
Amount & 0 & 16 & 130 & 215 & 44 & 405 & 0 & 4 & 32.1 & 53.1 & 10.9 \\
\hline
\end{tabular}

Based on the Table above, in general respondents who answered the number of their family members could influence the level of family consumption (STS) by $0 \%$, the number of their family members who were still in school affected family expenses (TS) by $4 \%$, the number of their family members who worked could affect the level of family income $(\mathrm{N})$ of $32.1 \%$, the number of their family members who work can affect the level of family consumption (S) of $53.1 \%$ increasing in family members, the more needs to be fulfilled (SS) of $10.9 \%$.

The number of family members of fishermen will affect consumption patterns household because each member of the household has different tastes (Fielnanda, 2018). The number of children who are still in school also affects family consumption because the amount of family income is not balanced with spending on children. The amount of children's allowance is not balanced with family income. However, there are also those who only have one child but spending a lot of consumption because different styles and tastes will affect the amount of goods consumed. So many or at least a child depends on the size of each style or taste in their daily needs will affect their consumption. Large need of children makes the head of the family have to work hard to get income to meet the needs of children (Junaidi et al., 2019).

Table 3 consists of descriptive statistics of the consumption pattern variable that also consists of five question items:

Table 3: Statistical description of consumption pattern

\begin{tabular}{lccccccccccc}
\hline \multirow{2}{*}{ Statements } & \multicolumn{4}{c}{ Static } & \multicolumn{3}{c}{ Total } & \multicolumn{5}{c}{ Percentage } \\
& STS & TS & N & S & SS & & STS & TS & N & S & SS \\
\hline Statement 1 & 0 & 15 & 30 & 33 & 3 & & 0 & 18.5 & 37 & 40.7 & 3.7 \\
Statement 2 & 2 & 21 & 15 & 36 & 7 & 81 & 2.5 & 25.9 & 18.5 & 44.4 & 8.6 \\
Statement 3 & 0 & 1 & 14 & 33 & 33 & 81 & 0 & 1.2 & 1.7 & 40.7 & 40.7 \\
Statement 4 & 0 & 3 & 35 & 34 & 9 & 81 & 0 & 3.7 & 43.2 & 42 & 11.1 \\
Statement 5 & 1 & 8 & 27 & 37 & 8 & 81 & 1.2 & 9.9 & 33.3 & 45.7 & 9.9 \\
Amount & 0 & 48 & 121 & 173 & 60 & 405 & 11.1 & 11.9 & 30 & 42.7 & 14.8 \\
\hline
\end{tabular}

Based on the table above, it is concluded that in one month (STS) by $11.1 \%$ of the income they used it for clothing needs: clothing, education, health (TS) by $11.9 \%$. From the income they got, they used it for board need: house, water, electricity, etc. (N) by 30\%. They used it for fishing gear: nets, machines, buoy, etc. (S) of $42.7 \%$. From the income they got, they used it for education of their family members and their health and family such as (SS), health insurance amount to $14.8 \%$.

Table 4 depicts the regression results based on t-statistics and Table 5 consist ANOVA. 
Table 4: Result of regression

\begin{tabular}{lccccc}
\hline \multirow{2}{*}{ Model } & \multicolumn{2}{c}{$\begin{array}{c}\text { Unstandardized } \\
\text { Coefficients }\end{array}$} & $\begin{array}{c}\text { Standardized } \\
\text { Coefficients }\end{array}$ & T & Sig. \\
& B & Std. Error & $\boldsymbol{\beta}$ & & \\
\hline Constant & -2.35 & 0.854 & 0.771 & -2.753 & 0.007 \\
Income & 0.908 & 0.055 & 0.247 & 16.51 & 0 \\
number of family members & 0.31 & 0.059 & & 5.294 & 0 \\
\hline
\end{tabular}

Note: Dependent Variable: consumption patterns

Table 5: Results of ANOVA

\begin{tabular}{lccccc}
\hline Model & $\begin{array}{c}\text { Sum of } \\
\text { Squares }\end{array}$ & Df & $\begin{array}{c}\text { Mean } \\
\text { Square }\end{array}$ & F & Sig. \\
\hline Regression & 728.245 & 2 & 364.123 & & \\
Residual & 79.557 & 78 & 1.02 & 356.996 & 0.000 \\
Total & 807.802 & 80 & & & \\
\hline
\end{tabular}

Note: Dependent Variable: consumption patterns

Income variable is found that the significance value is less than $5 \%$. Meanwhile, the value of tcount is greater than t Table $(16.510>1.990)$. It can be concluded that the income variable partially influences the consumption patterns of fishermen households. A positive $t$ value means that it has a positive effect, i.e. if the income variable increases, the consumption pattern variable will also increase. Variable number of family members is $<0.005$. Meanwhile, the value of $t$ statistic is $>t$ tabulated value $(5.294>1.990)$. It can be concluded that the variable number of family members partially influences the consumption patterns of fisherman households. The value of $t$ arithmetic is positive which means it is a positive effect, i.e. if the variable number of member family increases, then the consumption pattern variable will also increase.

The effect of independent variables simultaneously on the dependent variable is analyzed using the $\mathrm{F}$ test, namely by taking into account the significance of the $\mathrm{F}$ value at the calculation output with a level of $\pm 5 \%$. If the significance value of the $\mathrm{F}$ test is less than $5 \%$, there is an influence between all the independent variables on the dependent variable. The results of the $\mathrm{F}$ test in this study can be seen in the Table below. From the F test results in the Table 5, the significance value is $<0.05$ and the calculated $\mathrm{F}$ value is $>\mathrm{F}$ Table $(365.99>3.11)$. So it can be concluded that the two independent variables (income, number of family members) simultaneously influence the dependent variable (consumption patterns).

\section{CONCLUSIONS AND RECOMMENDATIONS}

From the obtained results it can be concluded that income influences the consumption patterns of fisherman household positively. The results also showed that the number of family members affected the consumption patterns of fisherman households.

The results of this study are consistent with Cindy (2016) which stated that the number of family members affected the consumption patterns of fishermen. The family or fisherman community needs to be empowered, nurtured and developed, in terms of knowledge, abilities and skills. So they have the opportunity to reach productive economic sectors.

About the conclusions and recommendations above, this study recommends as following:

1. Due to the increasingly low quality of human resources, and causing few opportunities to reach productive economic sectors, the steps that can be taken to deal with this problem can 
be done by designing and training packages that emphasize improving skills and practices to be able to work and trying to be more productive. The target of this program is the head of fisherman households who are less educated.

2. To increase the income of fisherman households, the government and other relevant stakeholders can increase entrepreneurial interest through providing working capital and coaching for poor households who are trying in the informal sector. With this assistance, the work done by poor households can be economically developed and profitable.

3. The burden of fishermen/poor households is more severe because there are many and less productive members. Looking at this fact it seems necessary to suggest birth control, especially in poor households that have many children. With this greater burden, efforts to improve the quality of human resources in poor households are difficult to develop. Increasing human resources of poor family members is a process that is believed to be able to reduce poverty in a relatively long time.

Funding: This study received no specific financial support.

Competing Interests: The authors declared that they have no conflict of interests.

Contributors/Acknowledgement: All authors participated equally in designing and estimation of current research.

Views and opinions expressed in this study are the views and opinions of the authors, Asian Journal of Agriculture and Rural Development shall not be responsible or answerable for any loss, damage or liability etc. caused in relation to/arising out of the use of the content.

\section{References}

Aries, D. (2015). Consumption Behavior of ABK Fishermen (Case Study of Fishermen Communities in Tasikagung Village. Rembang District, Rembang Regency, Central JavaIndonesia), (Thesis) Semarang: Semarang State University, Central Java Indonesia.

Astari, M., Yusman, S., \& Harianto. (2016). Patterns of household food consumption in west java province. Agro Economic Journal, 34(1), 67-80.

Carera, V. (2017). The Relationship Between Income and Consumption Patterns of Fishermen Communities in Ketapang Village. Padang Cermin District, Pesawaran Regency, Lampung Province, Indonesia (Thesis). Bandar Lampung: Faculty of Economics and Business, University of Lampung-Indonesia.

Cindy, O. S. (2016). Analysis of factors affecting household food consumption patterns (case study: Sungai Sungai village. Secanggang District, Langkat Regency-North Sumatra ProvinceIndonesia). Medan: Agribusiness Study Program Faculty of Agriculture, University of North Sumatra Medan-Indonesia.

Fajar, P., Rahayu, E. S., \& Marwanti, S. (2016). Analysis of maize farmer household consumption patterns in grobogan regency. Journal of AGRIC, 28(1-2), 41-54.

Fausi, M. E. Y. (2017). Analysis of household seaweed farmer household consumption expenditures in jeneponto regency. Sulawesi Province, Indonesian Notes (Thesis). Ujungpandang: Hasanuddin University Makassar-Indonesia.

Fielnanda, R. (2018). Consumption patterns of fishermen households in Mendahara Ilir village, mendahara district, tanjung jabung timur regency. Iltizam Journal of Shariah Economic Research, 2(2), 89-109.

Junaidi, A., Abdul, M., \& Ujan, M. (2019). Interview on the relationship between socio-economic status and consumption pattern of Indonesian fisherman households (study in karangsong coastal village. Indramayu Regency, West Java Province of Indonesia), August 23, 2019.

Kusnadi. (2007). Fishermen community life strategy. Yogyakarta: LkiS.

Mayasari, D., Dias, S., \& Iswan, N. (2018). Analysis of food consumption patterns based on HDI Status in East Java. Indonesian Journal of Economics and Development, 18(2), 191-213. 
Pande, P. E. A. (2012). The influence of family social and economic conditions on child labor motivation in helping families in Cirebon district of West Java. Journal of Development Economics, 1(1), 471-60.

Raharja, P., \& Mandala, M. (2005). Macroeconomic Theory. Jakarta: Faculty of Economics, University of Indonesia.

Riyadi, S. (2011). The effect of financial compensation, leadership costs \& work motivation on employee performance in manufacturing companies in East Java. Journal of Management and Entrepreneurship, 13(1), 40-45. https://doi.org/10.9744/jmk.13.1.40-45.

Uma, S. (2006). Research methods for business. Book Four Edition 1. Jakarta: Salemba Empat.

Vidiawan, E., \& Tisnawati, N. M. (2014). Analysis of the effect of income, number of family members and education on the number of poor household consumption in batu kandik village, nusa penida district, klungkung regency. E-Journal EP Unud, 4(40), 243-257. 